TURIZAM

Volume 23, Issue 3

133-144 (2019)

ORIGINAL

SCIENTIFIC PAPER

\section{Exploring the Gap in Destination Image and Destination Personality Perception Between Tourists and Stakeholders - Case of Roman Heritage Sites in Serbia}

\author{
Sanja Kovačić A* $^{*}$ Tamara JovanovićA ${ }^{A}$ Ivana Šagovnović ${ }^{A}$ \\ Received: August 2019 | Accepted: September 2019 \\ DOI: 10.5937/turizam23-22773
}

\begin{abstract}
The main aim of the paper is to determine if there is a difference in image and brand personality perception of the Roman heritage sites in Serbia between tourism stakeholders and tourists who have visited those sites. The initial assumption was that stakeholders in tourism have a more realistic perception of the current destination brand and image and that they are more aware of advantages and disadvantages related to the development of the analyzed Roman sites. To achieve the main aim of the study, the research has been done in two phases. The first phase included the survey done on the sample of 502 tourists who have visited some of the Roman sites in Serbia, while the second phase included an interview with 10 tourist stakeholders. The results show that tourism stakeholders have a more positive perception of both cognitive and affective image, with a special emphasis on affective image where the differences are quite large. In addition, the results indicate that tourists and tourist stakeholders equally perceive the analyzed Roman sites as Exciting. On contrary, tourist stakeholders have a better perception of all other dimensions of the brand personality, with the biggest difference being noticed in the perception of Ruggedness and Competence. Further differences will be discussed in the paper.
\end{abstract}

Keywords: Destination image, Destination personality, Cultural route, Roman heritage sites, Serbia

A University of Novi Sad, Faculty of Sciences, Department of Geography, Tourism and Hotel Management, TrgDositejaObradovića 3, 21000 Novi Sad, Serbia

* Corresponding author: sanja.bozic@dgt.uns.ac.rs 


\section{Introduction}

For tourism employees, it is important to know how tourists perceive the destination image and destination personality and whether it coincides with their personal perception of these destination components. If the difference is large, it is a sign that tourism employees did not succeed in presenting a destination on the market in the desired way. Moreover, for employees in tourism, it is significant to have information about tourists' behavior and their preferred activities. Thus, it is very important to analyze which factors affect these components. Numerous studies about image, brand personality and tourists' behavior (Frew, Shaw, 1999; Bigné et al., 2001; Barnes et al., 2014) emphasize the importance of such research for tourism stakeholders, especially in the terms of promotion and marketing planning. Thus, data obtained by comparing the perceptions of tourism employees and tourists can be used as guidelines for future development plans and promotion of certain destination on the target market. Therefore, it is important to analyze whether the image that tourists have about the destination coincides with how tourism stakeholders perceive this destination, as it will point out the significant fields on which they should focus in order to improve and develop destination image and brand.

Based on all of the above, the main aim of this paper is to examine if there is a difference in image and brand personality perception of the Roman sites in Serbia between key stakeholders working on tourism development at those sites and tourists/visitors of these sites.

The basic hypothesis of this research is:

Hypothesis 1: There is a difference in perceptions of image and brand personality betweentourism stakeholders and tourists who have visited the destination

It is believed that research will show the difference between how the image and brand personality is perceived by tourism stakeholders and tourists who have visited the sites. The reason for this assumption can be found in the fact that tourism stakeholders often have their vision of the image and brand personality of the destination they want to place and create in the mind of tourists, but they are not always successful in this. Similarly, stakeholders in tourism can have a more realistic perception of current image of the destination with a clear perception of how they want to build image and personality brand, while tourists can form their own perception of brand personality and image under the influence of various factors (the difference in sociodemographic characteristics, personality, activities in which they involve). Therefore, it is important that stakeholders are aware of these differences in order to adequately position the image of the destination.

\section{Literature review}

\section{The personality of the brand - destination}

The brand personality can be defined as a "set of human characteristics that are ascribed to the brand" (Aaker, 1997, p.347). For instance, those characteristics can be young, energetic, extravert, sophisticated, etc (Keller, 1998; Ekinci, Hosany, 2006). This suggests that consumers tend to personally identify with certain brands or to use brands as a means of personal expression (Kim, 2000). The best-known general scale for measuring brand personality is BPS (Brand Personality Scale), developed by Jennifer Aaker (1997). It is based on the Big Five personality model which measures personality traits. BPS consists of 4.2 items that measure five 
basic dimensions: Sincerity, Excitement, Competence, Sophistication, and Ruggedness. Confirmation of Aaker's model (1997) in different cultures showed that BPS results in relatively stable dimensions. Thus, this scale began to apply in the field of tourism. The research of the brand personality in the context of tourist destinations is relatively recent (Ekinci, Hosany, 2006; Gnoth et al., 2007; Hosany et al., 2006; Hosany et al., 2007; Pitt et al., 2007; Tasci, Kozak, 2006; Kim, Letho, 2013; Chon, Phau, 2013; Papadimitrou et al., 2014; Jovanović, 2014, 2017; Souiden et al., 2017; Kumar, Nayak, 2018; Chi et al., 2018; Lin, Roberts, 2019). In today's conditions, the destinations are identified with the brand and the personality traits can be assigned to the destinations (destination personality).Ekinci and Hosany (2006) were researchers who first applied BPS to the destination in order to evaluate its personality. They conducted their research among British tourists, applying a short version of the scale with 27 traits. The results of research extracted three dimensions that are specific to destinations: Sincerity, Excitement, and Conviviality. In addition, authors also discovered that destination personality shapes the relationship between perceived destination image and intention to recommend a destination. Other authors also investigated the personality of the destination and received different results. Some of them (Pitt et al., 2007; Sahin, Baloglu, 2009) in their research, used original BPS and results proved the five-factor structure of the brand personality. Relatively recent research by Usakli and Baloglu (2011) indicated the existence of five dimensions of destination personality:Vibrancy, Sophistication, Competence, Contemporary and Sincerity.The authors used a modified and shortened version of the original BPS. The analysis of literature suggests that there is a problem in determining the exact number of dimensions for describing the personality of the destination, mostly because of the application ofthe modified and shortened versions of the brand personality scales (Usakli, Baloglu, 2011; D’Astous, Boujbel, 2007), which makes comparison of the results more difficult. Similarly, some authors formed a scale themselves or accessed a different method (projective techniques, interviews). That indicated to the problem of the applicability of the original BPS to a tourist destination.This was also suggested by the first research of the destination personality among Serbian tourists, conducted by Jovanović(2014). Although the original BPS was used, the study showed that there is a need for designing a personality scale for the brand with items that will specifically describea tourist destination. In connection to this, Božić (2016) in her research, conducted also among Serbian tourists, modified the original Aaker's (1997) scale, creating a new scale that has the same dimension structure as BPS, but with 24 items that are adapted to the tourist destination. Hence, the shortcomings and problems of applying the BPS to the tourist destination have been overcome. This scale is named Destination Personality Scale (DPS) and it was used in the current study.

\section{Destination image}

The image of the destination, as well as a complex process of its forming, has a significant role in the consumers' behavior and their future intentions. Therefore, research has been focused on exploring the image of the destination for a long time. The authors from different fields define the image differently, which is also the case with destination image (Baloglu, 1997; Baloglu, McCleary, 1999; Baloglu, Brinberg, 1997; Tasci, 2003;Gallarza et al., 2002; Gartner, 1993; Kim, Richardson, 2003). This implies that there is no unique definition that can be accepted across various disciplines. Regarding the destination image, the definition formulated by Crompton (1979) is one of the most cited definitions. He defines the image as "the sum of beliefs, ideas, and impressions that tourists have of a particular destination".Other authors 
define destination image as a composition of a set of impressions that tourists have of a place (Gallarza et al., 2002; Campo-Martínez et al., 2010).

Two academic streams can be noticed in the research of the constitutive nature of destination image. Traditional stream supports the attitude that the image consists of a cognitive dimension (Mazursky, Jacoby, 1986), while the contemporary stream suggests that there are two dimensions: cognitive and affective image (San Martín, Rodríguez del Bosque, 2008). The cognitive dimension refers to the knowledge and belief of a person related to the attributes and features that distinguish an object or a place (Pike, Ryan, 2004; Stepchenkova, Mills, 2010). All emotions and feelings that a person possesses towards a particular object or place, relate to the affective dimension (Kim, Richardson, 2003). Some studies showed that, in order to understand the nature of the image, the optimal option isto include both dimensions, because the image is not made exclusively of the physical attributes and characteristics of the destination (Baloglu, 1997; Baloglu, McCleary, 1999). Moreover, some authors share the opinion that there is a third dimension (Gartner, 1993; Pike, Ryan, 2004) - a conative image that is associated with the behavior (e.g., the intention to visit the destination). In this paper, the destination image is measured by two components: cognitive and affective image.

\section{Methodology}

Sample

The study sample consists of tourists who have visited at least one site from the cultural route "The trail of the Roman Emperors". A total of 550 questionnaires were distributed, out of which 502 were validly filled, while 48 questionnaires were omitted from statistical analysis due to a large number of missing data (over 5\%). There are more female (63.3\%) than male respondents in the study sample. The average age of the respondents is 27.22 years, where the youngest respondent was 18 and the oldest 75 years. The highest percentage of respondents (half) has finished high school, while almost a quarter of the sample (23.3\%) has finished college. The highest percentage of respondents are students and employed people.Almost half of the respondents declared that they do not have income, which could be explained by a large number of students. The highest number of respondents is single. Most of the respondents have spent their childhood in the city, the village andtowns.

Research with the stakeholders of the route "The trail of the Roman Emperors" included 10 tourism stakeholders - one employee of the Museum of Roman Heritage, two professors of cultural tourism, a professor of history, two managers of the investigated Roman sites, one tour guide (employed in Roman site), an archaeologist (employed in Roman site) and two employees in the Tourist Organization of Serbia, one of whom is working on the product development - cultural tourism.

\section{Instruments}

A part of the questionnaire with tourists and stakeholders that was used for comparison, measured the cognitive and affective image and the personality of the destination of the last Roman site on the cultural route that respondents have visited. For the measurement of the cognitive image, as a basis were used scales developed by Echtner and Ritchie (1993) and Gallarza et al. (2002). However, items of these scales were adapted to a tourist destination in general, thus 
many of them did not match to the cultural route (e.g., water activities, opportunities for winter sports, nightlife and etc.). Therefore, the scale was adapted to the cultural route as a tourist destination, with prior consultation of experts (faculty professors of tourism and tourism employees at cultural route) who suggested which items should be excluded and which should be corrected and inserted, in order to measure the cognitive image of the cultural route. As a result, a scale containing 32 items was created, which respondents evaluated on the five-point Likert scale. Russell's (1980) bipolar pairs were used to measure the affective image. The scale for measuring the affective image was developed by a psychologist Russell (1980) who explored multidimensional and psychometric characteristics of effects. In his research, the author used a circular ranking technique, identifying eight categories of affects that are located in the coordinate system in a circular order: pleasure $\left(0^{\circ}\right)$, excitement $\left(45^{\circ}\right)$, arousal $\left(90^{\circ}\right)$, distress $\left(135^{\circ}\right)$, displeasure $\left(180^{\circ}\right)$, depression $\left(225^{\circ}\right)$, sleepiness $\left(270^{\circ}\right)$ and relaxation $\left(315^{\circ}\right)$. Eight interval positions are used to position emotional experience related to the observed object, which is described in the mentioned categories. Among the studies about the affective component of the image and brand of destinations (Kim, Richardson, 2003), special popularity gained a slightly simpler form of Russell' scale (1980) - bipolar pairs. Simplification of Russell's technique meant changing the circular ranking techniques with semantic differential scales. Consequently, for the purpose of measuring the affective image of the sites of the cultural route, five bipolar pairs were used and evaluated by five-step semantic-differentiated scales: exciting-depressing, interesting-boring, pleasant-unpleasant, useful-harmful, favorable-unfavorable. For measuring the personality of the brand, Destination Personality Scale (DPS) was used, developed by Božić (2016), which includes 5 dimensions of the original Brand Personality Scale (BPS) developed by Jennifer Aaker (1997), but with 24 items fully adapted to describe a tourist destination personality as a specific product. The items were evaluated on the five-point Likert scale from 1 (it does not describe it) to 5 (fully describes), where respondents assessed how much the destination personality trait describes the destination they have visited.

\section{Procedure}

The research was carried out through classic paper-pencil questionnaires at sites, but also via the online survey (Google Doc). Respondents filled in the questionnaires personally at the sites: Sirmium, Singidunum, Viminacium, Romuliana, Mediana and Justiniana Prima. The survey on the spot was not conducted at Roman sites in the Djerdap gorge (Pontes, Diana, Trajan's bridge and board), due to the absence of employed staff at the localities that would help in survey distribution, as well as the absence of a visitor center and poor site attendance. The questionnaire was distributed through the social network Facebook and by emailing friends and acquaintances, who distributed the questionnaire further (snowball technique was also applied). Tourists who have visited some of the sites on the cultural route "The trail of the Roman Emperors" in the past few years were asked to fill online questionnaire (Google Doc). A total of 164 online questionnaires were collected. All respondents were informed about the purpose of the research and that their participation is voluntary and anonymous.

The survey was conducted from February to August 2015. Questionnaires were distributed personally and with the help of colleagues at the sites, while a part of the questionnaires was collected by tour guides. Questionnaires were also collected in the buses during student field trips in East Serbia (Viminacium, Romuliana, Mediana, Justiniana Prima) and Vojvodina (Sirmium) with the help of teaching assistants and professors of the Department of Geography, Tourism and Hotel Management in Novi Sad. A total of 338 questionnaires were collected at the sites. 
For the investigation of the perception of the image and personality of the brand, semi-structured face-to-faceinterviews with 10 stakeholders were conducted at sites during 2016. Section of the interview related to destination personality and image was the same as the one in the survey for tourists, which enabled the comparison.

\section{Results}

With the principal aim of determining the difference between the image and destination personality perception by tourism stakeholders and tourists, an interview with tourism stakeholders and the survey with touristswere conducted.

The comparison of the image perception by tourists and tourism stakeholders is shown in Table 1. The results show that tourism stakeholders have a more positive perception of both cognitive and affective image, with a special emphasis on the affective image, where the differences are quite large.

Table 1. Differences in the perception of the image of the cultural route between tourists and tourism stakeholders

\begin{tabular}{|l|c|c|}
\hline Image & Tourists & Tourism stakeholders \\
\hline Mean cognitive image & 3.62 & 3.80 \\
\hline Mean affective image & .76 & 1.46 \\
\hline
\end{tabular}

Table 2. Differences in the perception of the cognitive image between tourists and tourism stakeholders (by items)

\begin{tabular}{|c|c|c|c|c|}
\hline & $\begin{array}{l}\text { Mean } \\
\text { Tourists }\end{array}$ & $\begin{array}{l}\text { Standard } \\
\text { Deviation }\end{array}$ & $\begin{array}{l}\text { Mean Tourism } \\
\text { Stakeholders }\end{array}$ & $\begin{array}{l}\text { Standard } \\
\text { Deviation }\end{array}$ \\
\hline Attractive cultural events and festivals & 3.35 & 1.088 & 2.89 & 1.054 \\
\hline Exciting activities & 3.33 & 1.110 & 3.44 & 1.236 \\
\hline Variety ofhandcraft and art & 3.29 & 1.076 & 2.67 & 1.323 \\
\hline Convenient climatic conditions & 3.62 & 1.050 & 3.89 & .928 \\
\hline $\begin{array}{l}\text { Excellent place to calm the mind and physical } \\
\text { relaxation }\end{array}$ & 3.70 & 1.122 & 3.78 & 1.716 \\
\hline $\begin{array}{l}\text { Excellent place to learn something about the rich } \\
\text { history of cultural sites }\end{array}$ & 4.34 & .881 & 4.78 & .441 \\
\hline Friendly and family environment & 3.56 & 1.016 & 3.89 & 1.167 \\
\hline $\begin{array}{l}\text { Great number of possibilities for staying and activities } \\
\text { in nature }\end{array}$ & 3.34 & 1.123 & 2.67 & 1.000 \\
\hline Affordable prices of food and accommodation & 3.32 & 1.069 & 4.00 & 1.118 \\
\hline $\begin{array}{l}\text { Interesting old buildings and remains of cultural } \\
\text { buildings }\end{array}$ & 4.28 & .930 & 4.67 & .707 \\
\hline Affordable local transport system & 3.28 & 1.068 & 2.44 & 1.333 \\
\hline Relaxed atmosphere & 3.97 & .915 & 4.33 & .866 \\
\hline $\begin{array}{l}\text { Good choice of different activities for men and } \\
\text { women }\end{array}$ & 3.06 & 1.065 & 2.44 & .882 \\
\hline The diverse offer of activities for children & 3.34 & 1.095 & 3.22 & 1.202 \\
\hline $\begin{array}{l}\text { Availability of tourist information of cultural heritage } \\
\text { at localities }\end{array}$ & 3.79 & 1.053 & 4.56 & .726 \\
\hline
\end{tabular}




\begin{tabular}{|c|c|c|c|c|}
\hline & $\begin{array}{l}\text { Mean } \\
\text { Tourists }\end{array}$ & $\begin{array}{l}\text { Standard } \\
\text { Deviation }\end{array}$ & $\begin{array}{l}\text { Mean Tourism } \\
\text { Stakeholders }\end{array}$ & $\begin{array}{l}\text { Standard } \\
\text { Deviation }\end{array}$ \\
\hline $\begin{array}{l}\text { A visit to cultural sites was worth (good value for } \\
\text { money) }\end{array}$ & 4.08 & .930 & 4.89 & .333 \\
\hline $\begin{array}{l}\text { Various entertainment opportunities in the area of } \\
\text { cultural sites }\end{array}$ & 3.16 & 1.052 & 3.22 & 1.093 \\
\hline Recognizable history and cultural heritage & 4.21 & .862 & 3.89 & .928 \\
\hline Safe and secure environment & 3.93 & .900 & 4.67 & .707 \\
\hline $\begin{array}{l}\text { Affordable prices for attractions and activities at } \\
\text { cultural sites }\end{array}$ & 3.12 & 1.120 & 4.11 & 1.167 \\
\hline Accessibility and availability of tourist sites & 3.65 & .991 & 3.78 & .667 \\
\hline $\begin{array}{l}\text { All components necessary to satisfy the needs of } \\
\text { elder people }\end{array}$ & 3.12 & 1.041 & 3.67 & .707 \\
\hline Interesting history of Southeast Europe & 4.11 & .955 & 4.44 & .726 \\
\hline $\begin{array}{l}\text { Help and support of information centers at cultural } \\
\text { sites }\end{array}$ & 3.49 & 1.047 & 4.11 & .782 \\
\hline $\begin{array}{l}\text { Nice natural environment (mountains, valleys, forests, } \\
\text { lakes, rivers) }\end{array}$ & 4.07 & 1.015 & 3.78 & 1.202 \\
\hline Good traffic infrastructure and parking information & 3.33 & 1.066 & 4.56 & .527 \\
\hline $\begin{array}{l}\text { Interesting supporting content such as exhibitions } \\
\text { and museum settings }\end{array}$ & 3.65 & 1.082 & 3.78 & .972 \\
\hline A good way to escape from everyday life & 3.96 & .988 & 4.22 & 1.093 \\
\hline Untouched nature and preserved living world & 3.45 & 1.122 & 3.56 & 1.014 \\
\hline Good terrain for camping, hiking, picnic, excursions & 3.28 & 1.159 & 3.22 & 1.093 \\
\hline $\begin{array}{l}\text { Hospitality and kindness of employees at cultural } \\
\text { sites }\end{array}$ & 3.95 & .927 & 4.22 & .667 \\
\hline Pleasant local people & 3.81 & .918 & 4.00 & 1.000 \\
\hline
\end{tabular}

Table 2. shows the differences in the perception of the cognitive image between tourists and tourism stakeholders by individual items. The results indicate that the greatest differences in perception can be found in the following items: Tourists consider more than tourism stakeholders that This route has attractive cultural events and festivals, Variety of handcraft and art, Great number of possibilities for staying and activities in nature, Affordable local transport system and Good choice of different activities for men and women.

On the other hand, it can be noted that tourism stakeholders give higher rankings to the following items: Affordable prices of food and accommodation, Availability of tourist information of cultural heritage at localities, Help and support of information centers at cultural sites, Safe and secure environment, Affordable prices for attractions and activities at cultural sites, Good traffic infrastructure and parking information. It is important to mention that there is a difference in the assessment of the Hospitality and kindness of employees at cultural sites and the Pleasant local people.

In addition, differences in the perception of the brand personality of the cultural route by dimensions were also analyzed (Table 3). 
Table 3. Differences in the perception of the brand personality between tourists and tourism stakeholders (by dimensions)

\begin{tabular}{|l|c|c|c|c|}
\hline & Mean & Std. Deviation & Mean & Std. Deviation \\
\hline Excitement & 3.51 & .949 & 3.50 & 1.165 \\
\hline Competence & 3.73 & .711 & 4.24 & .823 \\
\hline Ruggedness & 3.55 & .809 & 4.24 & .736 \\
\hline Sophistication & 3.59 & .897 & 3.75 & .433 \\
\hline Sincerity & 3.81 & .738 & 4.06 & .300 \\
\hline
\end{tabular}

Table 3. shows that tourists and tourism stakeholders equally perceive the analyzed cultural route as Exciting. In comparison with tourists, tourism stakeholdersevaluated more all other brand dimensions, while the biggest difference is in terms of the perceptions of Ruggedness and Competence. This means that tourism stakeholders perceive this destination as rugged and competent.

After the conducted analysis that indicatesa difference in the perception of image and brand personality between tourists and tourism employees, it can be concluded that Hypothesis 1 is accepted.

\section{Discussion}

The basic assumption of the study was that the stakeholders in tourism and tourists/visitors have a different perception of thecurrent image and destination personality. When it comes to the image of the cultural route, the results indicate that tourism stakeholders have a better perception of both cognitive and affective image, with a special emphasis on the affective image where the differences are quite large (average value for tourists is 0.76 , while for tourism stakeholders 1.46). Significant differences in terms of affective image could be explained by the fact that tourism stakeholders, who directly deal with the development of this cultural route, show certainbias, which prevents them from being objective in assessing the affective image. As the affective image relates to how we feel a certain destination, it is logical that those who are engaged in its development will perceive destination as a more entertaining, useful, favorable, etc. On the contrary, the cognitive image is based onthe facts and information we have about a certain destination, which are often more known to stakeholders than tourists. Since tourism stakeholders are working directly on the development of tourist destination, they are expected to have a more realistic perception of the cognitive image than tourists. In view of the cognitive image, the biggest differences exist in the following items: Tourists consider more than tourism stakeholders that this route has attractive cultural events and festivals, Variety of handcraft and art, Great number of possibilities for staying and activities in nature, Affordable local transport system and Good choice of different activities for men and women. On the other hand, it is noticeable that tourism stakeholders considerably evaluate more the following items: Affordable prices of food and accommodation, Availability of tourist information of cultural heritage at localities, Help and support of information centers at cultural sites, Safe and secure environment, Affordable prices for attractions and activities at cultural sites, Good traffic infrastructure and parking information. It is interesting to note that tourism stakeholders generally better evaluated the items that are related to infrastructure, prices, security and information, or items for which they themselves are the most responsible. The results indicate that the sites require more effort in terms of tourism infrastructure, as well as adapting 
the prices to tourists' needs.On the other hand, the results indicate that tourists have a better image of the destination offer (events, activities, art), but that tourism stakeholders must focus their activities primarily on improving tourism infrastructure and providing more information to tourists. Moreover, a better evaluation of the destination offer by tourists can be a consequence of the lack of information about the destination. It is important to mention that there is a difference regarding the assessment of Hospitality and kindness of employees at cultural sites and Pleasant local people, where it can be seen that tourism stakeholders give higher valuesto these items.This can be important information and stimulus for employees and local people to show a greater effort and provide a better service to tourists.

Research on the perception of destination personality by tourists and tourism stakeholders indicates that they equally perceive the analyzed cultural route as Exciting. It is encouraging fact that tourists and tourism stakeholders consider the destination as Exciting, which means that the theme itself, activities and facilities are really fun and dynamic, enough to make this destination attractive. On the other hand, tourism stakeholders higher evaluate all other dimensions of brand personality, while the biggest difference is in terms of the perception of Ruggedness and Competence. This means that tourism stakeholders consider this destination more competent and rugged than tourists. Therefore, tourists believe that this destination is less reliable, responsible, dedicated, serious, organized and helpful than tourism stakeholders. From this, it can be noted that tourism stakeholders do not have a realistic image of this and that they should much more listen to the criticism, recommendations and suggestions of tourists, in order to improve the current image of the destination. Tourism stakeholders also, perceive this destination as more Rugged (still insufficiently tamed, free, mysterious) than tourists, because they are aware of the fact that there is still many hidden and unexplored things in these locations, but also many projects that will be realized in the future. This finding is encouraging, as it indicates that tourism stakeholders are aware of the fact that some future discoveries and investments will contribute to the better positioning of this destination and their better promotion in the public.

\section{Conclusion and practical implications}

The basic hypothesis of this research was that there was a difference in the perception of image and destination personality among stakeholders that are employed at Roman heritage sites in Serbia and tourists who have visited these destinations. Comparison and analysis of the difference between image and destination personality perception of tourists and tourism employees have an important practical application. Whether the image that tourists have about the destination coincides with stakeholders' perception of the destination, it implies to the important fields on which they need to focus in terms of enhancement and future development of the image and brand of the destination. Therefore, confirming the presence of this difference is a significant contribution to theory and practice. The results indicate that tourism stakeholders have a more positive perception of both cognitive and affective image. This tells us again that tourism stakeholders are biased towards the tourist destination, which prevents them from having an objective view of the real situation, especially of infrastructure, prices, security and information - the items they are in charge for. The results indicate that stakeholders are aware that the sites require investment in infrastructure and much better promotion. However, they are still not aware of it as much as tourists.

Regarding destination personality, tourism stakeholders definitely consider a tourist destination more successful than tourists. This could be a problem, because they may not see a 
realistic pictureof the fields they need to improve - elements the tourists are not quite satisfied with. An adequate assessment of tourist satisfaction and their perception of certain components of the experience at the destination should be a guideline for tourism stakeholders when planning investments and improving the tourist product. The big problem is inadequate cooperation between individual stakeholders, because they are not familiar with the situation, investments or activities that exist in individual locations, but are more focused on isolated sites that are a place of their core business. Greater cooperation and the exchange of information between all sites on the route are important in order to position it as a unique product. From interviews with tourism stakeholders, it is also noticed that they consider that the basic problems of this cultural route are the lack of information for tourists and the inadequate promotion of the cultural route. Data obtained from this study can be used to develop the image and destination brand in the future, to indicates fields that require improvement, and to show what "characteristics" of the destination should be emphasized in destination promotion.

\section{References}

Aaker, J. L. 1997. Dimensions of brand personality. Journal of Marketing Research 34, 347-356.

Baloglu, S. 1997. The relationship between destination images and sociodemographic and trip characteristics of international travelers. Journal of Vacation Marketing 3(3), 221-233.

Baloglu, S., Bringer, D. 1997. Affective Images of Tourism Destinations. Journal of Travel Research 35(4), 11-15.

Baloglu, S., McCleary, K. W. 1999. A model of destination image formation. Annals of Tourism Research 26(4), 868-897.

Barnes, S. J., Mattsson J., Sørensen, F. 2014. Destination brand experience and visitor behavior: Testing a scale in the tourism context. Annals of Tourism Research 48, 121-139.

Bigné, J. E., Sánchez, M. I., Sánchez, J. 2001. The influence of market heterogeneity on the relationship between a destination's image and tourists' future behavior. Tourism Management 28(1), 175-187.

Božić, S. 2016. Uticaj ličnosti turiste na brend destinacije i turističko ponašanje na primeru lokaliteta kulturne rute (The impact of tourist personality on destination brand and tourist behavior on example of the sites of the cultural route) (Unpublished doctoral dissertation). Faculty of Sciences, University of Novi Sad.

Campo-Martínez, S., Garau-Vadell, J. B., Martínez-Ruiz, M. P. 2010. Factors influencing repeat visits to a destination: The influence of group composition. Tourism Management 31(6), 862-870.

Chen, C. F., Phou, S. 2013. A closer look at destination: Image, personality, relationship and loyalty. Tourism management 36, 269-278.

Chi, C. G. Q., Pan, L., Del Chiappa, G. 2018. Examining destination personality: Its antecedents and outcomes. Journal of Destination Marketing \& Management 9, 149-159.

Crompton, J. L. 1979. An assessment of the image of Mexico as a vacation destination and the influence of geographical location upon that image. Journal of Travel Research 17(4), 18-23.

D’Astous A., Boujbel, L. 2007. Positioning countries on personality dimensions: Scale development and implications for country marketing. Journal of Business Research 6o(3), 231-239.

Ekinci, Y., Hosany, S. 2006. Destination personality: an application of brand personality to tourism destinations. Journal of Travel Research 45(2), 127-139. 
Echtner, C. M., \& Ritchie, J. B. (1993). The measurement of destination image: An empirical assessment. Journal of travel research, 31(4), 3-13.

Frew, E. A., Shaw, R. N. 1999. The relationship between personality, gender, and tourist behavior. Tourist Management 20, 193-202.

Gallarza, M. G., Gil, I., Caldero'n, H. 2002. Destination image: Towards a conceptual framework. Annals of Tourism Research 29(1), 56-78.

Gartner, W. C. 1993. Image formation process. Journal of Travel and Tourism Marketing 2(2/3), 191-215.

Gnoth, J., Baloglu, J., Ekinci, Y., Sirakaya-Turk, E. 2007. Building destination brands. Tourism Analysis 12(5/6), 339-483.

Hosany, S., Ekinci, Y., Uysal, M. 2006. Destination image and destination personality: an application of branding theories to tourism places. Journal of Business Research 59, 638-642.

Hosany, S., Ekinci, Y., Uysal, M. 2007. Destination image and destination personality. International Journal of Culture, Tourism and Hospitality Research 1(1), 62-81.

Jovanović, T. 2014. Značaj individualnih vrednosti i personifikacije destinacije za izbor mesta i sadržaja (The significance of individual values and destination personification for the choice of holiday destination and content) (Unpublished doctoral dissertation). Faculty of Philosophy, University of Novi Sad.

Jovanović, T., Božić, S., Dinić, B., Majstorović, N. 2017. Serbian adaptation of the Brand Personality Scale (BPS): an application to tourism destinations. Primenjena Psihologija 10(1), 37-61.

Keller, K. L. 1993. Conceptualising, Measuring and Managing Customer-Based Brand Equity. Journal of Marketing 57, 1-22.

Kim, H., Richardson, L. S. 2003. Motion picture impacts on destination images. Annals of Tourism Research 30(1), 216-237.

Kim, H.-S. 200o. Examination of brand personality and brand attitude within the apparel product category. Journal of Fashion Marketing and Management 4(3), 243-252.

Kim, S., Lehto, X. Y. 2013. Projected and perceived destination brand personalities: The case of South Korea. Journal of Travel Research 52, 117-130.

Kumar, V., Nayak, J. K. 2018. Destination personality: Scale development and validation. Journal of Hospitality \& Tourism Research 42(1), 3-25.

Lin, N., Roberts, K. R. 2019. Destination personality: how to make the metaphor simpler? Anatolia, 1-12

Mazursky, D., Jacoby, J. 1986. Exploring the development of store image. Journal of Retailing 62(2), 145-165.

Papadimitriou, D., Apostolopoulou, A., Kaplanidou, K. 2014. Destination personality, affective image, and behavioral intentions in domestic urban tourism. Journal of Travel Research 20(10), 1-14.

Pike, S., Ryan, P. 2004. Destination Positioning Analysis through a Comparison of Cognitive, Affective, and Conative Perceptions. Journal of Travel Research 42, 333-342.

Pitt, L. F., Opoku, R., Hultman, M., Abratt, R., Spyropoulou, S. 2007. What I say about myself: communication of brand personality by African countries. Tourism Management 28(3), 835-844.

Russel, J. A. 1980. A Circumplex Model of Affect. Journal of Personality and Social Psychology 39, 1161-1178. 
Sahin, S., Baloglu, S. 2009. Brand personality and destination image of Istanbul: A comparison across nationalities. Paper presents at the 14th annual graduate student research conference in hospitality and tourism, Las Vegas, NV.

San Martín, H., Rodríguez del Bosque A. I. 2008. Exploring the cognitive-affective nature of destination image and the role of psychological factors in its formation. Tourism Management 29(2), 263-277.

Souiden, N., Ladhari, R., Chiadmi, N. E. 2017. Destination personality and destination image. Journal of Hospitality and Tourism Management 32, 54-70.

Stepchenkova, S., Mills, J. 2010. Destination image: a meta-analysis of 2000-2007 research. Journal of Hospitality Marketing and Management 19(6), 575-609.

Tasci, A. D. A., Kozak, M. 20o6. Destination brands vs destination images: do we know what we mean? Journal of Vacation Marketing 12(4), 299-317.

Usakli, A., Baloglu, S. 2011. Brand personality of tourist destinations: an application of self-congruity theory. Tourist Management 32(1), 114-127. 